\title{
Uluslararası Ticarette İnternet Kullanımının Rolü: Türkiye Örneği
}

\author{
The Role Of Internet Usage on Intertanional Trade: Evidence From Turkey
}

\author{
Ayberk ŞEKER ${ }^{1}$
}

\begin{abstract}
ÖZET
2000'li yıllarda internet kullanımı artarak küresel boyutlara ulaşmıştır. Bu çalışma kapsamında, internet kullanımının Türkiye'nin Avrupa Birliği ülkeleri ile toplam ticaret hacmi üzerindeki etkisi araştırılmıştır. Çalışmada, Türkiye ve 25 Avrupa Birliği üyesi ülkenin 2005 ve 2014 yılları arasındaki gayrisafi yurtiçi hâsıla, nüfus, ülkeler arası mesafe, internet kullanım oranları, ticari açıklıkları ve sivil özgürlük oranlarına ait veriler kullanılmıştır. İnternet kullanımının Türkiye'nin toplam ticaret hacmi üzerindeki etkisi dengeli panel veri analizi ve panel çekim modeli ile incelenmiştir. Çalışma sonucunda, internet kullanımının Türkiye'nin toplam ticaret hacmi üzerinde olumlu ve önemli etkilerinin olduğu tespit edilmiştir. Ayrıca, ülkelerin gayrisafi yurtiçi hâsılalarının, nüfuslarının ve ticari açıklık düzeylerinin artması ile Türkiye'nin söz konusu ülkeler ile ticaret hacminin artacağı, aralarındaki mesafenin ise ticaretlerini olumsuz etkilediği görülmüştür. Avrupa Birliği ülkelerinin sivil özgürlük oranının Türkiye'nin toplam ticaret hacmi üzerinde herhangi bir etkisi olmadığı tespit edilmiştir.
\end{abstract}

Anahtar Kelimeler: İnternet, Uluslararası Ticaret, Türkiye Ticaret Hacmi, Panel Veri, Çekim Modeli.

\section{GiRiş}

Türkiye'de, diğer ülkelerde olduğu gibi, 2000'li yıllar ile birlikte bilgi ve iletişim teknolojileri, önem kazanmaya başlamıştır. 2000'li yıllarda bilgi ve iletişim teknolojilerinin kullanımı hızla artmış, özellikle internet kullanımı hayatın her alanında önemli bir yere sahip olmaya başlamıştır. Gerek kamu kurumlarında gerek ticari işletmelerde gerekse de bireysel yaşamda bilgi ve iletişim teknolojileri işlemlerimizi hızlandıran ve hayatımızı kolaylaştıran önemli bir etmen olmuştur.

\begin{abstract}
Internet usage reached global dimensions in the 2000s. The main purpose of this paper is to investigate whether expansion of internet usage have a boosting impact on trade volume between Turkey and European Union countries. The empirical analysis is used data set of Turkey and 25 European Union countries from 2005 to 2014 . The data set includes GDP, population, distance, internet usage ratio, openness ratio and civil liberties ratio. To measure the impact of the internet usage upon Turkish international trade, we apply the method of strongly balanced panel data and panel gravity model. Results of panel data analyses and gravity model reveal that internet usage have meaningful impact on trade volume between Turkey and European Union countries. Furthermore, increasing of countries' GDP, population and opennes ratio boost trade volume between Turkey and European Union countries. On the other hand, distance among these countries decrease international trade volume of Turkey. Civil liberties ratios of European Union countries do not have any impact on Turkey's trade volume.
\end{abstract}

Keywords: Internet, International Trade, Turkish Trade Volume, Panel Data, Gravity Model.

Bilgi ve iletişim teknolojilerinin ticari hayat için en önemli aracı internet olarak karşımıza çıkmaktadır. Türkiye'de birçok kurumsal ve küçük işletme internet çağı ile birlikte kendilerine ait internet sayfaları açarak ticari, bilgi edinme ve pazara giriş maliyetlerini azaltma girişiminde bulunmuştur. 6102 sayılı Türk Ticaret Kanunu'nun 1524. maddesinin 1-6. fıkralarına göre, denetime tabi olan sermaye şirketlerinin ticaret siciline tescil tarihinden itibaren üç ay içerisinde internet sitesi açılması ve şirket tarafından kanunun öngördüğü bilgilerin yayınlanması zorunlu hale getirilmiştir. 
Böylelikle, şirketlerin internet sitelerinin bilgi toplumu hizmetlerine ayrılmış bölümü bilgilenmek isteyen herkesin erişimine açılmıştır.

Birçok ülke için bilgi ve iletişim teknolojilerinin kullanımının artması ile birlikte uluslararası ticareti teşvik eden faktörlerin de arttığı ve internetin ithalatihracat rakamlarını yükselttiği ortaya koyulmuştur. Türkiye'de de internet kullanımının yaygınlaşması ile birlikte uluslararası ticari faaliyetlerde bulunan işletmelerin ithalat ve ihracatlarındaki değişim, önemli bir araştırma konusu (sorusu) olarak karşımıza çıkmaktadır. Bununla ilgili literatürde bazı çalışmalar bulunmakla birlikte doğrudan Türkiye için bilgi ve iletişim teknolojilerinin uluslararası ticarete olan etkisi, internet ve buna bağlıyatırımlar ile birlikte araştırılarak bu etkinin ne yönde gerçekleştiğinin belirlenmesine yönelik çalışmalara çok fazla rastlanılmadığı yapılan literatür taraması ile görülmüştür.

Bu çalışma ile internet kullanımının Türkiye'nin uluslararası ticareti üzerindeki etkisinin araştırılması amaçlanmıştır. Literatürdeyapılan diğer çalışmalardan farklı olarak, Türkiye'deki internet kullanımına etki eden sivil özgürlük ortamının ve ticari açıklığın da çalışma kapsamında incelenerek Türkiye'nin uluslararası ticareti üzerinde kapsamlı bir analizi yapılmıştır. Bu doğrultuda, gerçekleştirilen çalışma ile internet kullanımının Türkiye'nin uluslararası ticareti üzerindeki etkisi panel çekim modeli vasıtasıyla değerlendirilmiştir.

Çalışma kapsamında gerçekleştirilen araştırmanın odak noktası ve literatüre katkısı, Türkiye'nin bilgi ve iletişim teknolojileri ile internet kullanımının uluslararası ticaret hacmini ne yönde etkilediğidir. Bu doğrultuda, gerçekleştirilen çalışma ile iki temel soruya cevap aranmıştır. İlki, internet kullanımının Türkiye'nin uluslararası ticaret hacminin artmasında etkili olup olmadığıdır. İkincisi ise, ülkelerin sivil özgürlük oranının internet kullanımını arttırması ile birlikte uluslararası ticaret hacmine nasıl bir etkide bulunduğudur.

\section{ULUSLARARASI TICARET ve INTERNET İLişKisi}

20. yüzyılın son çeyreğinde bilgi ve iletişim teknolojilerinde yaşanan büyük ilerlemeler küreselleşme sürecini hızlandırdığı gibi ülkelerin birbirleri ile olan ticaretlerine de önemli katkılarda bulunmuştur. Bilgi ve iletişim teknolojilerindeki gelişmeler, uluslararası ticareti çeşitli şekillerde ve boyutlarda etkilemiştir.

Bilgi ve iletişim teknolojilerindeki gelişmeler, ülkelerin birbirleri ile ticaretlerinde hem zaman hem de maliyet açısından önemli tasarruflar sağlamalarını mümkün kılmıştır (Freund ve Wienhold, 2002: 236; Clarke ve Wallstein, 2006: 468; Melemen, 2006: 193; Artan ve Kalaycı, 2009: 176). Bilgi teknolojileri kullanımının artması ile birlikte ülkeler arasındaki iletişim kolaylaşmış ve iletişim maliyetleri azalmıştır. Bilgi teknolojileri kullanımı ile hem bireysel kullanımlarda hem kamu kurumlarında hem de firmalarda zaman ve maliyet açısından tasarruf sağlanmıştır. Böylelikle, hızlı bir iş ve iletişim süreci başlamıştır (Freund ve Wienhold, 2004: 172).

Hızla gelişen iş ve iletişim teknolojilerindeki gelişmeler dış ticarette ödeme şekillerini de etkilemiştir. İletişim teknolojilerinin hızla gelişmesi ile birlikte, uluslararası ticarette tarafların bu duruma uyum sağlamaları ve bazı kuralları bu değişim ile uyumlu olarak değiştirmeleri zorunluluğu ortaya çıkmıştır. Uluslararası Ticaret Odası (ICC) tarafından bu süreçte oluşturulan kurallar ile akreditif ile ödeme şekilleri gibi bazı uygulamaları ülkelerin mevzuatlarıyla birlikte değerlendirilmesi sonucunda uluslararası ticaretin kolaylaştırılması ve arttırılması hedeflenmiştir (Yurtsever, 2010: 865-866).

Bilgi ve iletişim teknolojilerine verilen önem, kullanım ve yatıım miktarı ilgili ülkelerin milli gelirleri ile doğru orantılı olarak gerçekleşmektedir. Yüksek milli gelire sahip ülkeler bilgi ve iletişim teknolojilerine daha fazla yatırım yaparak zaman ve maliyet tasarrufu fırsatını büyük oranda gerçekleştirmiştirler (Lin, 2015: 424). Böylelikle, gelişmiş ülkeler ile düşük milli gelire sahip ülkelerin aralarındaki gelişmişlik düzeyi farkı daha da artmıştır. Gelişmiş ülkeler ile düşük milli gelire sahip olan ülkeler arasında yaşanan bu durum dijital bölünme olarak isimlendirilmektedir. Dijital bölünmeye uğrayan ülkelerin farklı ekonomik gelişmişlik düzeyleri sebebiyle kısıtlı teknolojiye sahip olmaları, düşük gelirli ülkelerin bilgi ve iletişim teknolojilerinin sağladığı ticari kolaylıklardan faydalanmalarını sınırlandırmıştır (Chinn ve Fairlie, 2007: 17; Yadav, 2014: 190).

Bilgi ve iletişim teknolojilerinin gelişmesi sonucunda, internet kullanımı yaygınlaşmıştır. Internet kullanımının artması ile birlikte, uluslararası ticarette piyasa bazlı ticaret maliyetlerinin azaltıldığı ileri sürülmektedir. Azalan ticaret maliyetleri 
sayesinde de ülkelerin ihracatlarının daha fazla gelişeceği belirtilmiştir (Bojnec ve Fertö, 2009: 125).

Bilgi ve iletişim teknolojileri gelişiminin ülkelerin içinde bulunduğu sivil özgürlük ortamından etkilendiği de ileri sürülmektedir. Sivil özgürlüklerin yoğun olduğu ülkelerde bilgi ve iletişim teknolojilerinin daha fazla geliştiği ve buna bağlı olarak da uluslararası ticaret hacimlerinin daha yüksek olduğu görülmüştür (Lin, 2015: 421).

Bilgi ve iletişim teknolojilerinin uluslararası ticarete etkisinde ülkelerin ticari açıklıklarının da önemli rolü bulunmaktadır. Ülkelerin ticari açıklık oranının internet kullanımı ve ekonomik büyüme üzerinde olumlu ve önemli bir etkiye sahip olduğu görülmüştür (Clarke ve Wallstein, 2006: 467; Meijers, 2014: 138).

\section{LITERATÜR TARAMASI}

Literatürde bilgi ve iletişim teknolojilerinin uluslararası ticaret üzerindeki etkisini analiz eden çeşitli çalışmalar bulunmaktadır. Bu çalışmalarda, uluslararası ticaret üzerinde etkili olabileceği düşünülen farklı değişkenler ile analizler gerçekleştirilmiştir.

Bu çalışmalardan ilki Freund ve Weinhold (2000, 2002, 2004) tarafından gerçekleştirilmiştir. Çalışmada 56 ülkeye ait 1995 - 1999 yılları arasındaki ihracat, gayri safi yurtiçi hâsıla, internet kullanımı ve ülkeler arasındaki mesafe değişkenleri kullanılarak çekim modeli vasıtası ile analizler gerçekleştirilmiştir. Araştırmacılar çalışmalarında, internetin uluslararası ticaret üzerinde teşvik edici bir etkisi bulunduğunu ortaya koymaktadırlar. Analizleri sonucunda, son yıllarda internetin uluslararası ticaret üzerinde yoğun bir etkiye sahip olduğunu ve bu etkinin ülkelerin internet kullanımının \%10 artışı karşısında ihracatlarının \%o 2 olarak gerçekleşeceği şeklinde olduğunu belirmiştirler.

Clarke ve Wallsten (2006), internetin uluslararası ticaret üzerindeki etkisini gelişmekte olan ülkelerin gelişmiş ülkelere ihracatını arttıracağı şeklinde açıklamışlardır. Çalışmada, yatay kesit regresyon yöntemi kullanılarak en küçük kareler (OLS) tahmincisi ile analizler gerçekleştirilmiştir. İnternet kullanımının artması ile birlikte ülkelerin ihracatlarında bir artış görüleceği belirtilmiştir. Bununla birlikte, ticari açıklığın da internet kullanımını teşvik edeceğini ifade etmişlerdir.

Melemen (2006) çalışmasında, Türk ihracat şirketlerinin internet ortamında bulunmalarının sağladığı faydaları araştırmıştır. İhracat alanında internet kullanımının yaygınlaşmasının dışa açılma ile yeni müşteri ve pazar bulunmasındaki etkisine odaklanmıştır. Bu doğrultuda, Türkiye ihracatındaki en büyük 500 şirketten 80 tanesi ile anket çalışması gerçekleştirmiştir. Araştırma sonucunda, şirketlerin ihracata başlamaları ile internet kullanma sürelerinin birbirleri ile aynı zamana denk geldiklerini ve internetin yeni pazar ve müşterilerin bulunmasında önemli derecede etkili olduğu görülmüştür.

Karagöz (2007) bilgi ve iletişim teknolojilerinin gelişmesinin ve yayılmasının Türkiye'nin ihracatı üzerinde arttırıcı bir etkisinin olup olmadığını analiz etmiştir. Çalışma kapsamında, ihracat, telekomünikasyon yatırımları, gayri safi yurtiçi hâsıla ve döviz kuru değişkenleri kullanılarak zaman serileri ve regresyon analizleri gerçekleştirilmiştir. Gerçekleştirilen analiz sonucunda, Türkiye'de telekomünikasyon yatırımlarının genel ihracat performansı üzerinde anlamlı bir etkiye sahip olmadığı, ekonomik büyüme ve dolar kurundaki artışın ise ihracat üzerinde olumlu bir etkiye sahip olduğu sonucuna varılmıştır.

İnternetin küreselleşmenin önemli bir gücü olduğunu belirten Clarke (2008) çalışmasında, Doğu Avrupa ve Orta Asya'daki düşük ve orta gelirli işletmelerden elde ettiği veriler ile internet erişiminin ihracat performansı üzerindeki etkisini araştırmıştır. Araştırma kapsamında, doğrudan yabancı sermaye yatırımları, kullanılan telefon hatları, uluslararası ekonomik örgütlere üye olma, nüfus ve mesafe gibi ihracat performansını etkileyen değişkenler çoklu regresyon ve panel regresyon yöntemleri ile test edilmiştir. Gerçekleştirilen analiz sonucunda işletmeler düzeyinde internet erişimi ve ihracat arasında kuvvetli bir ilişki olduğu ortaya koyulmuştur.

Artan ve Kalaycı (2009), Türkiye'nin de aralarında bulunduğu 30 OECD ülkesinde internetin uluslararası ticaret üzerindeki etkisini araştırmıştır. Bu doğrultuda, ülkelerin host $^{1}$ ve internet kullanıcı sayıları temel değişkenler olarak belirlenerek genelleştirilmiş çekim

'Host, Türkçe "Web Alanı" olarak adlandırılan, web sitelerine ait dosyaların barındığı web alanıdır. Web sitelerinin yapımı bittiğinde web sitelerine ait olan html, css, js, php, aspx, jsp vb uzantılı dosyalar ve tasarıma ya da içeriğe ait olan jpg, png, gif vb uzantılı resim dosyaları hostlara yüklenmektedir. 
modeli ve panel veri yöntemi ile analiz edilmiştir. 1997-2005 yıllarını kapsayan çalışmanın sonuçlarına göre, internetin uluslararası ticaret üzerindeki etkisinin anlamlı ve olumlu olduğu görülmüştür. İhracatçı ülkelerin host ve internet kullanıcılarının $\% 10$ artması ile uluslararası ticaretin \%1,6 ile \%6,8 civarında yükseleceği belirtilmiştir.

Bojnec ve Fertö (2009), internet kullanıcı sayısının OECD ülkeleri arasındaki ikili mal ihracatı üzerindeki etkisini araştırmışlardır. Çalışmada, çekim modeli kurularak panel veri ve yatay kesit regresyon yöntemleri kullanılmıştır. Araştırma sonuçlarına göre, internet kullanımı imalat sanayi ihracatını arttırmaktadır. Internet kullanımı ticaret maliyetlerini azaltmakta, rekabeti arttırmakta ve imalat sanayi ihracat hacmini yükseltmektedir. Bununla birlikte, internet kullanımının ithalatçı ülkelerde daha büyük bir etkiye sahipken, ihracatçı ülkede daha az bir etkiye sahip olduğu sonucuna varılmıştır.

Şen vd. (2009) çalışmalarında, yükselen piyasa ekonomilerinde ve gelişmiş ülkelerde ticaret hadlerinin belirlenmesinde bilgi ve teknoloji değişkenlerinin etkilerini araştırmışlardır. Çalışma kapsamında, 2001-2005 yılları arasında 22 yükselen piyasa ülkeleri ve 15 gelişmiş ülkenin verileri kullanılarak panel veri yöntemi ve en küçük kareler tahmincisi ile analizler gerçekleştirilmiştir. Analiz sonuçlarına göre, bilgi ve teknolojilerindeki değişimler, gelişmiş ülkelerin dış ticaret hadlerini ve net dış ticaretini açıklamada daha anlamlıdır. Modele teknoloji dışı değişkenlerin de ilave edilmesiyle modelin açıklama gücü yükselen piyasa ekonomileri için yükselirken, gelişmiş ülkeler açısından azalmıştır. Bununla birlikte, bilgi ve teknoloji değişimlerinin uluslararası ticaret üzerindeki etkisinin her iki ülke grubu için önemli derecede etkili olmadığını göstermişlerdir.

Vemuri ve Siddiqi (2009) çalışmalarında bilgi ve iletişim teknolojileri ve internet kullanımının uluslararası ticaret üzerinde geliştirici bir etkiye sahip olup olmadığını test etmektedirler. Çalışmada, 64 ülkeye ait 1985-2005 yılları arasındaki veriler ile panel veri analizi gerçekleştirilmiştir. Analiz sonuçlarına göre, bilgi ve iletişim teknolojileri altyapısı ve ticari işlemler için internet kullanımının uluslararası ticaret hacmi üzerinde anlamlı ve olumlu bir etkiye sahip olduğu ifade edilmiştir.

Çalışmasında uluslararası hizmet ticareti üzerinde internetin etkisini araştıran Choi (2010), ülkelerin internet kullanımlarının iki katına çıkarılması halinde uluslararası ticaret hacimlerinde \%2 ile \%4 civarında artış gösterdiğini ileri sürmüştür. Bu doğrultuda, ülkelerin internet erişimlerinde oluşabilecek artış sonrasında uluslararası hizmet ticareti hacminde de bir artış olacağı ifade edilmiştir. Çalışmada, uluslararası hizmet ticareti, ithalatı ve ihracatı, gayri safi yurtiçi hâsıla, nüfus, ticari açıklık ve internet kullanım oranı değişkenleri de modele dâhil edilerek çekim modeli kurulmuş ve panel veri analizi gerçekleştirilmiştir.

Miraskarivd.(2011), bilgiveiletişim teknolojilerinin ülkelerin ekonomik, sosyal ve kültürel kalkınmalarında önemli bir etken olduğunu ileri sürmüşlerdir. Çalışma kapsamında, 30 ülkenin 2001-2008 yılları arasındaki gayrisafi yurtiçi hâsıla, nüfus, mesafe ve host verileri kullanılarak panel veri analizi gerçekleştirilmiştir. Gerçekleştirilen çalışmada, internetin ticaret akımları üzerindeki etkisi araştırılmıştır. Analiz sonuçlarına göre, artan sayıdaki internet kullanıcılarının ihracatçı ve ithalatçı ülkelerde ticaret hacmini ve ihracatı $\% 5$ seviyelerinde arttırdığı tespit edilmiştir.

Sosyal ve teknolojik ağların uluslararası ticaret üzerindeki etkisini inceleyen Lee (2012), 23 OECD ülkesine ait veriler ile ülkeler arasındaki ticareti değerlendirmek amacıyla çekim modeli kapsamında regresyon analizi gerçekleştirmiştir. Analiz sonuçlarına göre, internetin imalat ve hizmet sektörü ticaretinde anlamlı ve en önemli unsur olduğu belirtilmiştir.

Timmis (2012) çalışmasında internet kullanımının OECD ülkeleri arasındaki uluslararası ticaret üzerine etkisini çekim modeli ile analiz etmiştir. Analizler sonucunda, ticaret akımları üzerinde internetin önemli derecede bir etkisi olmadığı ileri sürülmüştür. Internet kullanımının yüksek olduğu ülkelerde diğer ülkelere göre daha fazla ticaret ilişkisi olduğu ifade edilmiştir.

Gelişmekte olan ülkelerde internetin uluslararası hizmet ticareti üzerindeki etkisini araştıran Salmani vd. (2013), çalışmaları sonucunda internetin uluslararası hizmet ticareti üzerinde önemli ve pozitif bir etkiye sahip olduğu sonucuna varılmıştır. Bununla birlikte, uluslararası hizmet ticareti ile gayri safi yurtiçi hâsıla, finansal derinlik ve nüfus arasında pozitif bir ilişki olduğu ileri sürülmüştür. Çalışmada, dengesiz panel veri ve çekim modeli analizi kullanılmıştır.

Meijers (2014) çalışmasında internet kullanımının uluslararası ticaret ve ekonomik büyüme üzerindeki etkisini dengesiz panel veri yöntemi ile araştırmıştır. Çalışma sonucunda, internet kullanımının ekonomik 
büyüme üzerinde direkt olarak etkili olmadığı ancak ticari açıklığa sahip ülkelerin internet kullanımı ile uluslararası ticaretleri arasında yüksek bir ilişki olduğu ortaya koyulmuştur. İnternet kullanımının artışı düşük gelirli ülkelerin ticaretlerinde daha yüksek bir etkiye sahipken, ekonomik büyüme üzerindeki etkisi hem düşük gelirli hem de yüksek gelirli ülkeler için aynı düzeyde etkiye sahip olduğu ifade edilmiştir.

İnternet kullanımının artmasının uluslararası piyasalara girişte bilgiye dayalı maliyetleri azaltacağını ileri süren Yadav (2014) çalışmasında, internet kullanımının Asya ve Afrika'daki gelişmekte olan ülkelerin firmaları üzerindeki etkisini ikili seçim modeli ve panel veri analizi ile araştırmıştır. Çalışma sonuçlarına göre, e-posta ve internet sayfası kullanımı ihracat ve ithalat hacminin artmasını sağlamıştır.

Bilgi ve iletişim teknolojileri ile ticaret akımları arasındaki ilişkiyi inceleyen Yushkova (2014)'nın çalışmasında, uluslararası ticarette işletmelerin internet kullanımının yaygınlaşması ve bilgi ve iletişim teknolojilerinin uluslararası ticaretteki rolü değerlendirilmiştir.Çalışmada, çekimmodelikurularak panel veri sabit etkiler tahmini gerçekleştirilmiştir. Analiz sonucunda, internet kullanımı ve bilgi ve iletişim teknolojileri ürünleri ticareti arasında pozitif ilişki olduğu iddia edilmiştir.

Lin (2015) çalışmasında, internet kullanımının uluslararası ticareti teşvik edici etkisini incelemiştir. Çalışmada, internetin uluslararası ticarette enformasyon maliyetlerini azalttı̆̆ı ifade edilmiştir. Çalışma kapsamında ele alınan veriler çekim modeli ile analiz edilmiştir. Analiz sonuçlarına göre, internet kullanımında \%10 artışın uluslararası ticareti \%o 2 ile \%o 4 seviyelerinde yükselttiği sonucuna varılmıştır.

Salmani vd. (2015) çalışmasında, İslam İşbirliği Teşkilatı ülkelerinde internet kullanımının uluslararası hizmet ticareti üzerindeki etkisini çekim modeli ve dengesiz panel veri analizi ile araştırmıştır. Analiz sonuçlarına göre, internetin İslam İşbirliği Teşkilatı ülkelerinin hizmet ticareti üzerinde olumlu ve büyük bir etkiye sahip olduğu ortaya koyulmuştur. Bununla birlikte, hizmet ticareti ile gayri safi yurtiçi hâsıla, finansal derinlik ve nüfus arasında da pozitif bir ilişkinin olduğu sonucuna varılmıştır.

\section{ARAŞTIRMA}

\subsection{Araştırma Yöntemi ve Veri Seti}

Çalışma kapsamındaki araştırma sorularına cevap bulabilmek amacıyla; Türkiye ve Avrupa Birliği'ne (AB) üye 25 ülkenin 2005 ve 2014 yılları arasındaki dönemi kapsayan gayri safi yurtiçi hâsıla, ülke nüfusları, ülke mesafeleri, internet kullanım oranı, sivil özgürlük oranı ve ticari açıklık oranları ile panel çekim modeli kurularak analizler gerçekleştirilmiştir.

Araştırmada bağımlı değişken olarak yer alan Türkiye'nin $A B^{\prime}$ ne üye 25 ülke ile gerçekleştirdiği toplam ticaret ve ihracatına ilişkin veriler, T.C. Gümrük ve Ticaret Bakanlığı veri tabanından edinilmiştir. Ülkelerin gayrisafi yurtiçi hasılaları, nüfusları ve ticari açıklıklarına ilişkin veriler ise Dünya Bankası veri tabanından edinilmiştir. Ülkelerin Türkiye'ye olan kuş uçuşu uzaklıkları Centre d'Etudes Prospectives et d'Informations Internationales (CEPII)'den ${ }^{22}$ edinilirken, sivil özgürlük oranları ise dünyada özgürlük ve demokrasi genişlemesine adanmış bağımsız bir kuruluş olan Freedom House'tan edinilmiştir. Araştırma kapsamında kullanılan veri seti, 2005 ve 2014 yılları arasına ait verilerden oluşmaktadır.

Çalışmada kullanılan değişkenlere ait bilgiler şu şekildedir;

Toptichac: Türkiye'nin 25 AB ülkesi'ne gerçekleştirdiği ihracatı ile ilgili ülkelerden gerçekleştirdiği ithalatın toplamıdır.

Gsyih: Ülkelere ait gayrisafi yurtiçi hâsıla rakamlarıdır. Nufus: Ülkelerin nüfuslarıdır.

Mesafe: Türkiye ile $25 \mathrm{AB}$ ülkesinin başkentleri arasındaki kuş uçuşu uzaklıktır.

Internet: Ülkelerin internet kullanım oranlarından oluşmaktadır.

Ticariaciklikoran: Ülkelerin ithalat ve ihracat toplamlarının gayrisafi yurtiçi hâsılalarına oranındaki değişim oranıdır.

Sivilozgoran: Ülkelerin sivil özgürlük oranına ait değişim oranıdır.

\subsubsection{Panel Veri Analizi ve Panel Çekim Modeli}

Panel veri analizi yapılmasının temel nedeni, internet kullanımı ve uluslararası ticaret arasındaki ilişkinin hem zaman etkisinin hem de kesit etkisinin

${ }^{2}$ CEPII (Centre d'Etudes Prospectives et d'Informations Internationales) 1978 yılında kurulmuş olan ve uluslararası ekonomi üzerinde çalışmalar, araştırmalar, veri tabanları ve analizler gerçekleştiren Fransız araştırma merkezidir. 
incelenerek daha geçerli ve güvenilir bir analiz gerçekleştirilmesinin istenmesidir.

Panel veri analizi kapsamında oluşturulan çekim modeli, uluslararası ticarette ülkelerin ticaret hacimlerinin ve dış ticaretlerindeki belirleyicilerinin tahmin edilmesi amacıyla çok sık kullanılmaktadır. Çekim modeli, Newton'un ortaya koyduğu çekim yasasına dayanmaktadır.

Uluslararası ticarette panel çekim modelinin ilk uygulamaları Tinbergen (1962), Pöyhönen (1963) ve Linneman (1966) tarafından gerçekleştirilmiştir. Newton'un çekim yasasından esinlenerek oluşturulan çekim modeline göre; ülkelerin birbirleri arasındaki ticaret hacimleri ekonomik büyüklükleri ve nüfusları ile doğru orantılı iken, aralarındaki uzaklık arttıkça ticaret maliyetleri de artacağı için mesafe ile ters orantılı olduğu ortaya koyulmaktadır (Baltagi, 2015:608). Geleneksel çekim modelinin eşitlik olarak ifadesi aşağıdaki gibidir;

$T_{i j}=\alpha_{0} Y_{i}^{\alpha 1} Y_{j}^{\alpha 2} D_{i j}^{\alpha 3}$

Geleneksek çekim modeline göre (1) ülkelerin ekonomik büyüklükleri ile ticaretin artması, mesafelerine göre de ticaretlerinin azalması beklenmektedir. Ancak zamanla uluslararası ticarette ülkelerin ticaretlerindeki yoğun etkileri dolayısıyla çeşitli faktörler devreye girmiştir. Ülkelerin teknolojilerinin gelişmesi, uluslararası ticarete olan açıklıklarının artması gibi faktörler uluslararası ticareti etkilemeye başlamıştır.
$Y_{i t}=\beta_{1}+\beta_{2} X_{2 i t}+\beta_{3} X_{3 i t}+u_{i t}$

Çekim modeli için hazırlanan panel veri setlerinin (2) analizlerinde "klasik doğrusal modeller", "sabit etkiler modeli" ve "tesadüfî etkiler modeli" kullanılmaktadır. Standart çekim modellerinde ticaret akımlarını tahmin etmek amacıyla genellikle kesit veriler analiz edilmektedir. Ancak, panel verinin kullanılmasıyla modele zaman etkisi de dâhil edilerek modele temsil edilmeyen yılların etkisinin dâhil edilmesi riski ortadan kaldırılmaktadır. Ayrıca, panel verinin kullanılması ticaret yapan ülkeler arasındaki gözlemlenemeyen birim etkilerin görülmesine imkân tanımaktadır (Gujarati, 2003:636-638). Panel veri setinde, ticaret ortakları örnekleminin daha büyük bir örneklem grubu arasından seçilmesi halinde tesadüfi etkiler modelinin kullanılmasının daha uygun olacağı ileri sürülmektedir. Buna karşılık, daha önceden belirli koşulları sağlayan ülkelerin ticaret akımlarının incelenmesi durumunda sabit etkiler modelinin kullanılmasının daha verimli olacağı düşünülmektedir (Antonucci ve Manzocchi, 2006: 161).

Bu bilgiler ışığında, Türkiye ile AB üyesi 25 ülkenin ticaretleri üzerinde internet kullanımının artmasıyla ortaya çıkan sonuçların analiz edilebilmesi amacıyla aşağıdaki panel çekim modeli oluşturulacaktır (3);

$$
\begin{aligned}
& \quad \ln \left(\text { toptichac }_{i j}\right)_{t}=\beta_{0}+\beta_{1} \ln \left(\text { gsyih }_{i j}\right)_{t}+\beta_{2} \ln \left(\text { nufus }_{i j}\right)_{t} \\
& \left.+\beta_{3} \ln \left(\text { mesafe }_{i j}\right)_{t}+\beta_{4} \text { (internet }_{i j}\right)_{t}+\beta_{5}\left(\text { sivilozg }_{i j}\right)_{t}+\beta_{6} \\
& \text { (ticariaciklik } \left._{i j}\right)_{t}+\varepsilon_{i j t}
\end{aligned}
$$
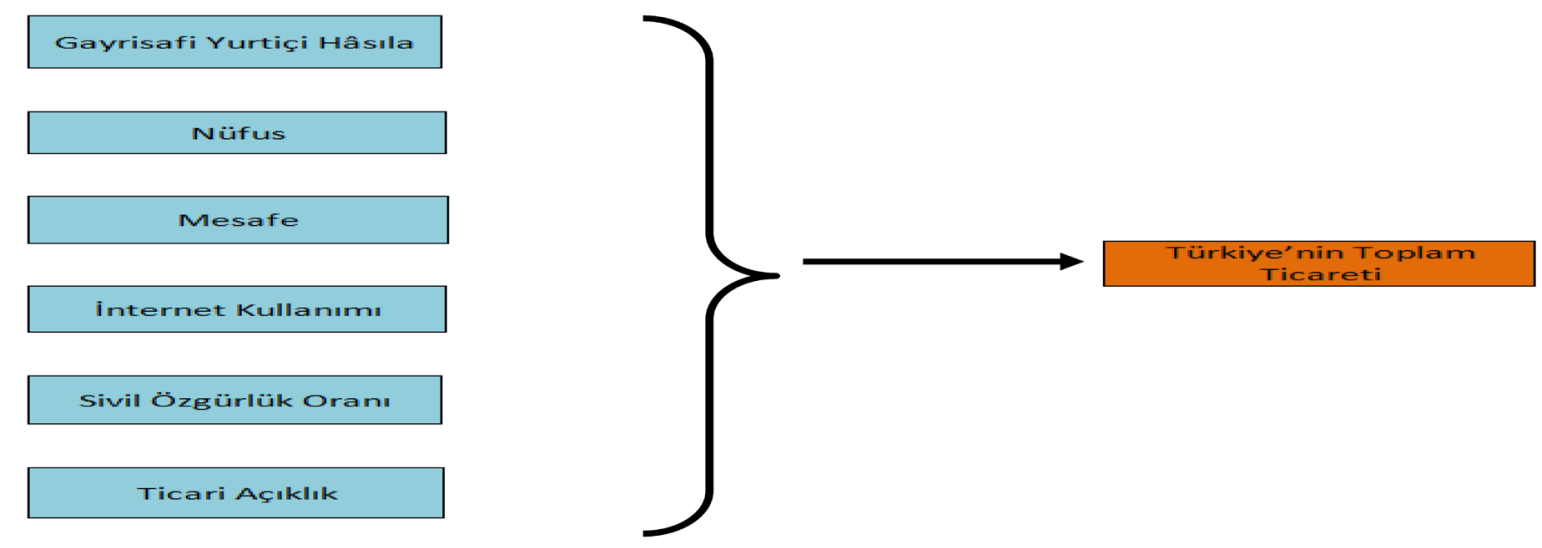

2005

2014

Şekil 1: Araştırma Modeli 


\subsection{Araştırma Hipotezleri}

Çalışmanın hipotezleri belirlenmiştir;

$\mathrm{H}_{1}$ : Gayrisafi yurtiçi hâsıla ile Türkiye'nin toplam ticareti arasındaki ilişkinin pozitif yönde olması ve gayrisafi yurtiçi hâsılada meydana gelen artışın Türkiye'nin toplam ticaretini arttırması beklenmektedir.

$\mathrm{H}_{2}$ : Ülkelerin nüfusları ile Türkiye'nin toplam ticareti arasında pozitif yönde bir ilişki beklenmektedir. Ülkelerin nüfuslarının yükselmesi Türkiye'nin toplam ticaretinde olumlu etki yaratacaktır.

$\mathrm{H}_{3}$ : Ülkelerin Türkiye ile arasındaki mesafe ile Türkiye'nin toplam ticareti arasında negatif yönde bir ilişki beklenmektedir. Ülkelerin Türkiye'ye olan uzaklıklarının artması Türkiye'nin toplam ticaretinde olumsuz bir etki meydana getirecektir.

$\mathrm{H}_{4}$ : Ülkelerin bilgi ve iletişim teknolojilerinin gelişmesi ile birlikte internet kullanımının yaygınlaşmasının Türkiye'nin toplam ticaret hacmini olumlu yönde etkileyeceği beklenmektedir.

$\mathrm{H}_{5}$ : Ülkelerin sivil ve sosyal hayatlarındaki özgürlükleri ile Türkiye'nin ticaret hacmi arasında olumlu bir ilişki beklenmektedir.

$\mathrm{H}_{6}$ : Ülkelerin uluslararası ticaretlerine açıklıkları ile Türkiye'nin ticaret hacmi arasındaki ilişkinin pozitif yönde olacağı beklenmektedir. Ülkelerin ticarete açık olmaları Türkiye ile ticaret hacimlerini arttıracaktır.

\subsection{Veri Analizi}

Panel veri analizlerinde, öncelikle serilerin durağan biryapıya sahip olup olmadığı incelenmelidir. Durağan olmayan zaman serilerinin kullanılması durumunda, sahte regresyon sorunu ortaya çıkabilmekte ve elde edilen sonuçlar değişkenler arasındaki gerçek ilişkiyi yansıtmayabilmektedir.

Panel birim kök analizi gerçekleştirilerek verilerin durağanlığı test edildikten sonra, panel çekim modeli analizine geçilerek internet kullanım oranındaki değişimlerin Türkiye'nin 25 AB üyesi ülke ile gerçekleştirdiği ticari faaliyetler üzerindeki etkisi incelenmiştir.

\subsubsection{Panel Veri Durağanlığının Sınanması}

Araştırmanın temel sorunsalı, internet kullanım oranındaki gelişmelerin ortaya çıkaracağı avantajı durumlar ile Türkiye'nin toplam ticaret hacminde ve toplam ihracatında artış şeklinde bir etkide bulunacağı şeklindedir. Türkiye'nin toplam ticaret hacmi ve ihracatı ile internet kullanım oranı arasındaki ilişki panel veri analizi ile gerçekleştirilmiştir. Öncesinde panel verilerin durağanlığının test edilmiş ve Tablo 1 'de sonuçlar verilmiştir.

Tablo 1: Panel Birim Kök Test Sonuçları

\begin{tabular}{|c|c|c|c|c|c|c|c|c|}
\hline \multirow{3}{*}{ Değişkenler } & \multicolumn{4}{|c|}{ Levin, Lin \& Chu Birim Kök Testi } & \multicolumn{4}{|c|}{ Augmented Dickey Fuller-Fisher Birim Kök Testi } \\
\hline & \multicolumn{2}{|c|}{ Düzey } & \multicolumn{2}{|c|}{ 1. Fark } & \multicolumn{2}{|c|}{ Düzey } & \multicolumn{2}{|c|}{ 1. Fark } \\
\hline & Sabit & $\begin{array}{c}\text { Sabit + } \\
\text { Trend }\end{array}$ & Sabit & $\begin{array}{l}\text { Sabit + } \\
\text { Trend }\end{array}$ & Sabit & $\begin{array}{c}\text { Sabit + } \\
\text { Trend }\end{array}$ & Sabit & $\begin{array}{c}\text { Sabit + } \\
\text { Trend }\end{array}$ \\
\hline Lntichactop & $\begin{array}{l}-8,895 \\
(0,000) \\
\end{array}$ & $\begin{array}{r}-16.375 \\
(0,000) \\
\end{array}$ & $\begin{array}{c}-17.454 \\
(0,000) \\
\end{array}$ & $\begin{array}{c}-17.958 \\
(0,000) \\
\end{array}$ & $\begin{array}{l}79.196 \\
(0,005) \\
\end{array}$ & $\begin{array}{c}58.469 \\
(0.1924)\end{array}$ & $\begin{array}{l}171.97 \\
(0,000)\end{array}$ & $\begin{array}{l}98.033 \\
(0,000)\end{array}$ \\
\hline Lngsyih & $\begin{array}{r}-14.522 \\
(0,000)\end{array}$ & $\begin{array}{r}-17.747 \\
(0,000)\end{array}$ & $\begin{array}{r}-13.019 \\
(0,000)\end{array}$ & $\begin{array}{r}-11.353 \\
(0,000)\end{array}$ & $\begin{array}{l}175.88 \\
(0,000)\end{array}$ & $\begin{array}{c}105.226 \\
(0,009)\end{array}$ & $\begin{array}{c}156.564 \\
(0,000)\end{array}$ & $\begin{array}{l}82.600 \\
(0,002)\end{array}$ \\
\hline Lnnufus & $\begin{array}{l}-3.238 \\
(0,000)\end{array}$ & $\begin{array}{r}-28.535 \\
(0,000)\end{array}$ & $\begin{array}{c}-26.268 \\
(0,000)\end{array}$ & $\begin{array}{c}-41.756 \\
(0,000)\end{array}$ & $\begin{array}{l}180.17 \\
(0,000)\end{array}$ & $\begin{array}{c}139.204 \\
(0,000)\end{array}$ & $\begin{array}{l}124.52 \\
(0,000)\end{array}$ & $76.078(0,010)$ \\
\hline İnternet & $\begin{array}{l}-7.034 \\
(0,000) \\
\end{array}$ & $\begin{array}{r}-10.437 \\
(0,000) \\
\end{array}$ & $\begin{array}{l}-7.078 \\
(0,000) \\
\end{array}$ & $\begin{array}{c}-11.326 \\
(0,000) \\
\end{array}$ & $\begin{array}{l}170.38 \\
(0,000) \\
\end{array}$ & $85.191(0,001)$ & $\begin{array}{c}205.477 \\
(0,000) \\
\end{array}$ & $186.701(0,000)$ \\
\hline Sivilozgoran & $\begin{array}{l}-5.453 \\
(0,000)\end{array}$ & $\begin{array}{c}-4.96462 \\
(0,000)\end{array}$ & $\begin{array}{l}-2.688 \\
(0,003)\end{array}$ & $\begin{array}{l}-6.008 \\
(0,000)\end{array}$ & $\begin{array}{l}45.229 \\
(0,000)\end{array}$ & $42.976(0,000)$ & $\begin{array}{l}74.971 \\
(0,000)\end{array}$ & $58.698(0,000)$ \\
\hline Ticariaciklikoran & $\begin{array}{c}-13.354 \\
(0,000)\end{array}$ & $\begin{array}{r}-11,931 \\
(0,000)\end{array}$ & $\begin{array}{l}-21,095 \\
(0,000)\end{array}$ & $\begin{array}{c}-16,788 \\
(0,000)\end{array}$ & $\begin{array}{l}132,92 \\
(0,000)\end{array}$ & $\begin{array}{l}76,854 \\
(0,008)\end{array}$ & $\begin{array}{l}201,97 \\
(0,000)\end{array}$ & $\begin{array}{c}121,462 \\
(0,000)\end{array}$ \\
\hline
\end{tabular}

Not: Gecikme uzunlukları Schwarz Bilgi Kriteri'ne göre seçilmiştir. Parantez içindeki değerler testlerin P-değerlerini göstermektedir. 
Tablo 1'de görüldüğü üzere, değişkenlerin tümü için düzey halindeki serilerin durağan olduğu açıkça görülmektedir. Levin, Lin ve Chu ile Augmented Dickey Fuller-Fisher birim kök testleri ile elde edilen sonuçlara göre tüm seriler düzeyde tümleşik yapıya sahip olduğundan panel veri analizlerine geçilmesinde herhangi bir sakınca bulunmamaktadır.

\subsubsection{Panel Veri Analizi}

Panel veri analizinde öncelikle çalışmanın tahmin tekniğine karar vermek amacıyla birtakım testler uygulanacaktır. Bu kapsamda panel verilere sırasıyla; Olabilirlik Oranı Testi, Breusch-Pagan Lanrange Çarpan Testi, Score Testi ve Hausman Testi uygulanacaktır.

Uygulanacak olan Olabilirlik Oranı Testi, BreuschPagan Lanrange Çarpan Testi ve Score Testi ile klasik (havuzlanmış) model, tesadüfi etkiler modeline karşı test edilmektedir. Belirtilen testlerin $\mathrm{H}_{0}$ hipotezleri, klasik modelin tesadüfi etkiler modeline göre daha uygun olduğu üzerine kurulmaktadır. Alternatif hipotez ise, tesadüfi etkiler modelinin uygun olduğunu ifade etmektedir.

Tablo 2: Olabilirlik Oranı Testi, Breusch-Pagan Lanrange Çarpan Testi ve

Score Testi Sonuçları

\begin{tabular}{|l|c|c|c|c|}
\hline Testler & Chibar2(01) & Chi2(1) & Prob>=Chibar2 & Prob>=Chi2 \\
\hline Olabilirlik Oranı Testi & 440.45 & - & 0,000 & - \\
\hline Breusch-Pagan Lanrange Çarpan Testi & 825.72 & - & 0,000 & - \\
\hline Score Testi & - & $1.1 \mathrm{e}+05$ & - & 0,000 \\
\hline
\end{tabular}

Tablo 2'de test istatistikleri ve olasılık değerleri yer almaktadır. Test istatistikleri, 1 serbestlik dereceli $x^{2}$ tablosu ile karşılaştırılarak elde edilmektedir. Sonuçlara göre, birim etkilerin standart hatalarının sıfıra eşit olduğunu belirten $\mathrm{H}_{0}$ hipotezi reddedilerek klasik modelin analiz için uygun teknik olmadığı ortaya koyulmuştur.

Tablo 3: Hausman Test Sonuçları

\begin{tabular}{|l|c|c|c|}
\hline Değişkenler & S.E. & T.E. & Fark \\
\hline Lngsyih & 0.8433396 & 0.8447403 & -0.0014007 \\
\hline Lnnufus & -1.468705 & -0.0737114 & -1.394993 \\
\hline Lnmesafe & -24.49685 & -1.349874 & -23.14697 \\
\hline İnternet & 0.0136424 & 0.0127068 & 0.0009357 \\
\hline Sivilozgoran & 0.0353185 & -0.0067722 & 0.0420908 \\
\hline Ticariaciklikoran & 0.0065374 & 0.0061644 & 0.0003729 \\
\hline \multicolumn{2}{|c|}{ Hausman Test İstatistiği } & & 0.1291 \\
\hline \multicolumn{2}{|c|}{ Prob>chi2 } \\
\hline
\end{tabular}

Klasik modelin uygun olmadığına karar verildikten sonra, sabit etkiler ve tesadüfi etkilerin karşılaştırıldığı Hausman Testi gerçekleştirilmiştir. Uygun tahmincinin seçimi için gerçekleştirilen Hausman Testi sonucunda, tesadüfi etkiler tahmincisinin sabit etkiler tahmincisine göre analiz için daha uygun olduğu tespit edilmiştir. Bu nedenle, gerçekleştirilen testlerin sonuçları doğrultusunda tesadüfi etkiler modeli kullanılarak analize devam edilecektir.
Panel veri modellerinde hata teriminin birimler içerisinde ve birimler arasında eşit varyansın (homoskedastik) olduğu kabul edilmektedir. Bununla birlikte, hata terimlerinde dönemsel ve uzamsal olarak korelasyon bulunmadığı varsayılmaktadır (Tatoğlu, 2013: 197). Bu varsayımların tesadüfi etkiler modeli için test edilmesi gerekmektedir.

Tesadüfi etkiler modelinde eşit varyansın olmaması ve hata terimleri arasında korelasyon 
bulunması halinde heteroskedasite ve otokorelasyon gibi sorunlar ile karşılaşılmaktadır. Tesadüfi etkiler modelinde, heteroskedasite sorununun tespit edilmesi amacıyla kullanılan test, Levene, Brown ve Forsythe Testidir.

Tablo 4: Levene, Brown ve Forsythe Testi Sonuçları

\begin{tabular}{|l|c|c|c|}
\hline & Test İstatistikleri & Serbestlik Dereceleri (df) & Prob. \\
\hline $\mathbf{W}_{\mathbf{0}}$ & 7.0854696 & 24,225 & 0.000 \\
\hline $\mathbf{W}_{\mathbf{5 0}}$ & 4.4137788 & 24,225 & 0.000 \\
\hline $\mathbf{W}_{\mathbf{1 0}}$ & 6.5404253 & 24,225 & 0.000 \\
\hline
\end{tabular}

Tablo 4'te elde edilen sonuçlara göre, Levene, Brown ve Forsythe test istatistikleri $(24,225)$ serbestlik dereceli Snedecor F tablosu ile karşılaştırılmış ve birimler arası varyansın eşit olduğuna dayanan hipotez reddedilmiştir. Bu doğrultuda, tesadüfi etkiler modelinde heteroskedasite bulunduğu ortaya koyulmuştur.

Tesadüfi etkiler modeli temel varsayımlarından bir diğeri hata terimleri arasında otokorelasyonun bulunmaması varsayımıdır. Ekonomik verilerin sınandığı modellerde, ekonomide yaşanan şokların etkisi birden fazla dönemi etkilemesi nedeniyle hata terimleri arasında korelasyona neden olmaktadır. Bu doğrultuda, tesadüfi etkiler modellerinin hata terimlerinde zamana göre korelasyon çok sık görülebilmektedir (Tatoğlu, 2013: 225). Dolayısıyla, tesadüfi etkiler modelinde otokorelasyon varlığı test edilmeli ve olması halinde uygun yöntemler kullanılmalıdır. Tesadüfi etkiler modelinde otokorelasyon varlığı, Bhargava, Franzini ve Narendranathan'ın Durbin Watson Testi, BaltagiWu'nun Yerel En İyi Değişmez Testleri ile Lanrange Çarpanı ve Düzeltilmiş Lanrange Çarpanı Testleri vasıtasıyla sınanmıştır.

Tablo 5: Bhargava, Franzini ve Narendranathan'ın Durbin Watson Testi ve

Baltagi-Wu'nun Yerel En lyi Değişmez Testi Sonuçları

\begin{tabular}{|l|c|}
\hline Bhargava, Franzini ve Narendranathan'ın Durbin Watson Testi & 0.91267253 \\
\hline Baltagi-Wu'nun Yerel En İyi Değişmez Testi & 1.1446564 \\
\hline
\end{tabular}

Tablo 5'te bulunan test sonuçlarında her iki testin de tesadüfi etkiler modeli için belirlenen " 2 " kritik değerinden küçük olduğu görülmektedir.
$\mathrm{Bu}$ doğrultuda, tesadüfi etkiler modelinde birinci dereceden otokorelasyon bulunduğu tespit edilmiştir.

Tablo 6: Lanrange Çarpanı Testi ve Düzeltilmiş Lanrange Çarpanı Testi Sonuçları

\begin{tabular}{|l|c|c|}
\hline & Test İstatistiği & Prob. \\
\hline Lanrange Çarpanı Testi & 247.82 & 0.000 \\
\hline Düzeltilmiş Lanrange Çarpanı Testi & 10.45 & 0.001 \\
\hline
\end{tabular}

Tablo 6'da ise, otokorelasyonun sıfıra eşit olduğu hipotezinin sınandığı otokorelasyon testi olan Lanrange Çarpanı ve Düzeltilmiş Lanrange Çarpanı testlerinin sonuçları görülmektedir. Bu testlerin sonuçlarına göre, otokorelasyonun bulunmadığı hipotezi reddedilerek otokorelasyonun varlığı tespit edilmektedir.
Tesadüfi etkiler modelinde temel varsayımlardan bir tanesi de hata terimlerinin birbirlerinden bağımsız yapıda olduklarıdır. Birimler arası korelasyonun varlığını sınamak amacıyla Pesaran, Friedman ve Frees Testleri gerçekleştirilmiştir. 
Tablo 7: Pesaran ve Friedman'ın Yatay Kesit Bağımsızlık Testi Sonuçları

\begin{tabular}{|l|c|c|}
\hline \multicolumn{1}{|c|}{ Testler } & Test İstatistiği & Prob. \\
\hline Pesaran'ın Yatay Kesit Bağımsızlık Testi & 11.509 & 0.000 \\
\hline Friedman'ın Yatay Kesit Bağımsızlık Testi & 39.406 & 0.0247 \\
\hline
\end{tabular}

Tablo 7'de, sıfır hipotezi birimler arasında korelasyonun bulunmadığı üzerine kurulan Pesaran ve Friedman testlerinin sonuçları bulunmaktadır. Elde edilen sonuçlara göre, her iki test sonucunda da sıfır hipotezinin reddedilerek modelin birimler arası korelasyona sahip olduğu görülmüştür. Bununla birlikte Tablo 8'de sonuçları bulunan Frees testinde elde edilen test istatistiği tüm düzeylerdeki kritik değerden yüksek bulunmuş ve modelin birimler arası korelasyona sahip olduğu doğrulanmıştır.

Tablo 8: Frees'in Yatay Kesit Bağımsızlık Testi Sonuçları

\begin{tabular}{|l|c|}
\hline \% 99 düzeyindeki kritik değer & 0.5198 \\
\hline \% 95 düzeyindeki kritik değer & 0.3429 \\
\hline \% 90 düzeyindeki kritik değer & 0.2559 \\
\hline Frees'in Yatay Kesit Bağımsızlık Testi İstatistiği & 2.684 \\
\hline
\end{tabular}

Gerçekleştirilen testler sonucunda tesadüfi etkiler modelinin panel veri analizi için uygun olduğu bulunmuş ve bu tesadüfi etkiler modelinin heteroskedasite, otokorelasyon ve birimler arası korelasyona sahip olduğu tespit edilmiştir. Panel veri analizinin son aşamasında, tesadüfi etkiler modelinde heteroskedasite, otokorelasyon ve birimler arası korelasyon olduğu varsayımları altında modelin geçerli sonuçlar vermesini sağlayan dirençli tahminci kullanılarak geçerli sonuçlar elde edilmiştir. Panel veri analizi kapsamında veriler arasındaki ilişkide tespit edilen yatay kesit bağımlılığının (birimler arası korelasyon) seriler üzerinde ortaya çıkarabileceği olumsuz etkileri ortadan kaldıran dirençli tahminciler ile analiz edileceği için yalnızca birinci nesil birim kök analizi kullanılmıştır.

Panel veri analizinde kullanılan dirençli tahminciler heteroskedasite otokorelasyon ve birimler arası korelasyon durumlarında, varyansların, standart hataların, $t$ ve $F$ istatistiklerinin ve $\mathrm{R}^{2 \prime}$ nin geçerliliklerinin sağlanması amacıyla kullanılan yöntemlerdir. Panel veri modellerinde, heteroskedasite, otokorelasyon veya birimler arası korelasyon durumlarından en az birinin bulunması halinde ya parametre tahminlerini değiştirmeden standart hatalar düzeltilmeli ya da uygun yöntemler ile tahminler gerçekleştirilmelidir (Tatoğlu, 2013: 241). Bu doğrultuda, çalışma kapsamında oluşturulan modelde heteroskedasite, otokorelasyon ve birimler arası korelasyon bulunması nedeniyle bu varsayımlar altında geçerli tahminde bulunmamızı sağlayan Driscoll ve Kraay dirençli tahmincisi kullanılmıştır.

Driscoll ve Kraay dirençli tahmincisi zaman serisi kovaryans matris tahmincilerinin uzamsal ve dönemsel korelasyonun tüm formları için dirençli olarak geliştirilmiş bir yöntemdir. Driscoll ve Kraay dirençli tahmincisinin metodolojisi, serilerin yatay kesit ortalamaları serisi için Newey-West türü düzeltme işlemi uygulamaktadır. Bu doğrultuda, düzeltilmiş olan standart hata tahminleri, yatay kesit boyutundan $(\mathrm{N})$ bağımsız olarak kovaryans tahmincilerinin tutarlılığını sağlamaktadır (Tatoğlu, 2013: 266). Başka bir ifade ile, Driscoll ve Kraay dirençli tahmincisi heteroskedasite, otokorelasyon ve birimler arası korelasyon (yatay kesit bağımlılığı) koşulları altında dirençli standart hatalar üreterek seriler üzerindeki olumsuz etkileri ortadan kaldırıp tutarlı tahminde bulunulmasını sağlamaktadır. 
Tablo 9: Tesadüfi Etkiler Modeli Driscoll ve Kraay Dirençli Tahmincisi Sonuçları

\begin{tabular}{|l|c|c|}
\hline Lntoptichac & Katsayılar & P-Değeri \\
\hline Lngsyih & 0.6685757 & 0.000 \\
\hline Lnnufus & 0.1425622 & 0.004 \\
\hline Lnmesafe & -0.9872205 & 0.000 \\
\hline Internet & 0.0042617 & 0.039 \\
\hline Sivilozgoran & -0.5737336 & 0.430 \\
\hline Ticariaciklikoran & 0.0065874 & 0.067 \\
\hline Sabit & 8.924484 & 0.000 \\
\hline$R^{2}$ & \\
\hline F( 6, 9) & 60075.28 & \\
\hline
\end{tabular}

Tablo 9'da yer alan tesadüfî etkiler modeli Driscoll Kraay dirençli tahmincisi sonuçlarına göre, ülkelerin ekonomik büyüklüklerini ve arz-talep düzeylerini gösteren gayrisafi yurtiçi hâsılanın Türkiye'nin toplam ticaret hacmi üzerinde $\% 1$ düzeyinde anlamlı bir etkisinin olduğu görülmüştür. Ülke nüfuslarının anlamlı ve pozitif yönde bir etkisinin bulunduğu tespit edilirken, ülkelerin birbirleri olan mesafelerinin Türkiye'nin toplam ticaret hacminde $\% 1$ düzeyinde anlamlı ve olumsuz yönde bir etkide bulunduğu ortaya koyulmuştur. Avrupa Birliği ülkelerinin internet kullanım oranlarının Türkiye ile gerçekleşen ticaretlerinde \% 5 düzeyinde anlamlı ve pozitif yönde etkisi olduğu görülürken, ülkelerin içinde bulunduğu sivil özgürlük ortamının Türkiye'nin ticaret hacmi üzerindeki etkisinin anlamlı olmadığı tespit edilmiştir. Avrupa Birliği ülkelerinin toplam ithalat ve ihracatlarının gayrisafi yurtiçi hâsılalarına oranlarının, başka bir ifade ile ticari açıklık oranlarının ise, Türkiye'nin toplam ticaret hacmine olumlu ve $\% 10$ düzeyinde anlamlı bir etkisinin olduğu ortaya koyulmuştur.

Gerçekleştirilen panel veri analizi sonucunda, çalışma kapsamında oluşturulan araştırma hipotezlerinden gayrisafi yurtiçi hâsılanın Türkiye'nin toplam ticareti üzerindeki anlamlı ve olumlu etkisi olacağını belirtilen $H_{1}$ hipotezi kabul edilmiştir. Bununla birlikte, ülke nüfusları ile Türkiye'nin toplam ticareti arasında anlamlı ve pozitif bir ilişkinin beklendiği $\mathrm{H}_{2}$ hipotezi, ülkelerin Türkiye'ye olan mesafeleri ile Türkiye'nin toplam ticareti arasında anlamlı ve negatif yönde bir ilişkinin olacağının ileri sürüldüğü $\mathrm{H}_{3}$ hipotezi, internet kullanımının yaygınlaşmasının Türkiye'nin toplam ticaret hacmini anlamlı ve olumlu yönde etkileyeceği belirtilen $\mathrm{H}_{4}$ hipotezi ve ülkelerin uluslararası ticarete açıklıkları ile Türkiye'nin ticaret hacmi arasındaki ilişkinin pozitif ve anlamlı olacağı ortaya koyulan $\mathrm{H}_{6}$ hipotezi çalışmanın kapsadığı 2005 ve 2014 yılları arasındaki süreç için kabul edilmiştir. Buna karşın, ülkelerin sivil ve özgürlükleri ile Türkiye'nin ticaret hacmi arasında anlamlı ve olumlu bir ilişkinin beklendiği $\mathrm{H}_{5}$ hipotezi reddedilmiştir.

Model sonuçlarına göre, Avrupa birliği ülkelerinin ekonomik büyüklüğünü ve talep hacmini oluşturan gayrisafi yurtiçi hâsılalarındaki bir birimlik yükseliş, Türkiye'nin toplam ticaret hacminde 0,67 birimlik artış sağlamaktadır. Avrupa Birliği ülkelerinin nüfuslarında bir birimlik artış ise, Türkiye'nin toplam ticaretinde 0,14 birimlik yükselme sağlamaktadır. Buna karşılık, Türkiye ile Avrupa Birliği ülkeleri arasındaki mesafenin bir birimlik artışı ile Türkiye'nin toplam ticaret hacminde 0,98 birimlik azalma olacağı görülmektedir. Mesafenin artması ile ticaret masraflarının yükselmesinin uluslararası ticareti azaltan etkisi modelde açık bir şekilde görülmüştür.

Çalışmanın odak noktası olan internet kullanımı ve uluslararası ticaret ilişkisine baktığımızda, model sonuçlarına göre Avrupa Birliği ülkelerindeki internet kullanım oranının bir birimlik artışı ile Türkiye'nin toplam ticaret hacminin 0,004 birim artacağı görülmektedir. İnternet kullanım oranının artması ile ülkelerin uluslararası ticaret maliyetleri azalmakta ve ticaretlerinde artış gözlemlenmektedir. Model kapsamındaki bir diğer değişken olan Avrupa Birliği ülkelerinin ticari açıklıklarındaki bir birimlik artışın Türkiye'nin toplam ticaret hacminde 0,006 birimlik bir artış sağlayacağı görülmüştür. Avrupa Birliği 
ülkelerinin ithalat ve ihracat eğiliminin artması Türkiye ile olan uluslararası ticaretine olumlu bir şekilde yansımaktadır.

Model sonuçlarına göre, modele dâhil edilen bağımsız değişkenlerin bağımlı değişkenin \% $81,8^{\prime}$ ini açıklama gücüne $\left(R^{2}=0,818\right)$ sahip olduğu görülmüştür. Modelin anlamlılığı ise, $F$ testinin istatistik değeri ve olasılık değerinin oldukça büyük olması sebebiyle $[F(6,9)=60075.28$, Prob. $>F=0.000]$ yüksektir.

\section{SONUÇ ve DEĞERLENDIRME}

İnternet kullanımının artması yalnızca bireysel kullanımlar ile bireylerin kişisel yaşamlarını değil, ülkelerin uluslararası ticaretlerini de kolaylaştıran bir etmen olmuştur. Özellikle uluslararası ticarette internet kullanımı ile pazara giriş, rekabet avantajı, reklam ve tanıtım gibi önemli maliyetlerin azalması ile birlikte, ülkelerin uluslararası ticaretlerinde artışlar söz konusu olmuştur. Uluslararası ticaret işlemlerinin internet ortamı üzerinden gerçekleştirilmesi ile zaman ve mesafe sınırlamaları ortadan kaldırılmakta ve yerel işletmelerin uluslararası pazarlara girişleri daha da kolaylaşmaktadır.

Çalışma kapsamında internetin Türkiye'nin 25 Avrupa Birliği üyesi ülke ile gerçekleştirdiği uluslararası ticaret üzerindeki etkileri değerlendirilmiştir. Bu doğrultuda, ülkelerin internet kullanım oranları çekim modeline dâhil edilerek panel veri analizleri gerçekleştirilmiş̧ir. Analizler sonucunda, ülkelerin ekonomik büyüklüklerini temsil eden gayrisafi yurtiçi hâsılalarının literatürle uyumlu bir şekilde Türkiye ile 25 Avrupa Birliği üye ülkesi arasındaki ticareti olumlu yönde etkileyen bir gösterge olduğu ortaya koyulmuştur. Ülkelerin Türkiye'ye olan uzaklıkları ise Türkiye'nin Avrupa Birliği üye ülkeleri ile ticaretinin maliyetlerini yükseltmesi sebebiyle olumsuz yönde etkilediği tespit edilmiştir. Bununla birlikte, ülkelerin nüfuslarının literatürde beklendiği üzere Türkiye'nin ticaretinde olumlu etkiye sahip olduğu görülmüştür. Ülkelerin ticaret gerçekleştirmeye olan açıklık oranlarının ise literatürle uyumlu olarak Türkiye'nin ticaret hacmi üzerinde pozitif yönde bir etki oluşturduğu tespit edilmiştir. Tüm bu bulgular doğrultusunda; ülkelerin üretim hacimlerini arttırmaları, internet kullanım oranlarının arttırıması ve ticari açıklık oranlarının yükseltilmelerinin uluslararası ticaret hacimleri üzerinde ticareti arttıran bir etkiye sahip olacağı görülmüştür.

Araştırmanın odak noktasını oluşturan internetin uluslararası ticaret üzerindeki etkisinin analiz kapsamındaki dönemler itibariyle olumlu yönde olduğu ortaya koyulmuştur. Bu olumlu etki doğrultusunda, ülkelerin hem internet altyapılarını hem de uluslararası ticaretlerini geliştirmek amacıyla bilgi ve iletişim teknolojileri üzerine yaptıkları yatırımlarını ve bu yatırımların niteliklerini arttırmaları önerilmektedir. Gerçekleştirilen panel veri analizi doğrultusunda, ülkelerin internet kullanımlarının Türkiye'nin ticaret hacmi üzerindeki etkisi beklenenden daha az olduğu görülmüştür. Bu noktada, hem Türkiye'de hem de ticaret gerçekleştirdiği ülkelerde internet altyapılarına yapılan yatırımların arttırıması hem de ticaret hayatında internet kullanımının yükseltilmesine yönelik önlemlerin alınması gerekmektedir. Böylelikle, ülkeler uluslararası ticaretteki maliyetlerini azaltarak daha yüksek hacimde uluslararası ticaret gerçekleştirme imkânına kavuşabileceklerdir.

Uluslararası ticarette internet kullanımının arttırılması ile birlikte ülkeler alışılagelmiş maliyeti yüksek ticaret yöntemleri yerine daha modern, maliyet ve zaman açısından daha uygun uluslararası ticaret yöntemleri kullanma imkânına kavuşacaklardır. Böylelikle, ülkelerin uluslararası ticaret hacimleri artacak ve maliyetlerin azalması dolayısıyla uluslararası ticaret yapan işletmelerin sayısında artış gözlemlenebilecektir. Gerçekleştirilen çalışma ile Türkiye ve 25 Avrupa Birliği ülkesi arasında 2005 ve 2014 dönemi içerisinde yapılan ticarette internet kullanımının etkisi ölçülmek istenmiştir. Ancak, günümüzde hem Türkiye hem de diğer ülkeler için birçok önemli ticaret pazarı oluştuğundan yapılan analizler bu pazarlara da uygulanarakgenişletilmelidir. Bu doğrultuda, bu alanda gerçekleştirilecek ileriki çalışmalarda internet kullanımının artmasıyla birlikte uluslararası ticarette çeşitlenen aktörlerin artışı da araştırılmalıdır. Özellikle yüksek ticaret maliyetleri sebebiyle uluslararası ticarete entegrasyonu sağlanamayan gelişmemiş ve gelişmekte olan ülkelerin internet kullanım olanaklarının artmasıyla uluslararası ticaretteki rollerinin incelenmesi gelecek çalışmalar için büyük önem arz etmektedir. 


\section{KAYNAKLAR}

Antonucci, D. ve Manzocchi, S. (2006) "Does Turkey Have A Special Trade Relation with the EU? A Gravity Model Approach", Economic System, 30: 157 - 169.

Artan, S. ve Kalaycı, C. (2009) "Internetin Uluslararası Ticaret Üzerindeki Etkileri: OECD Ülkeleri Örneği", Doğuş Üniversitesi Dergisi, 10(2): 175 - 187.

Baltagi, B. H. (2015) The Oxford Handbook of Panel Data, England, Oxford University Press.

Bojnec, S. ve Fertö, I. (2009) "Impact of the Internet on Manufacturing Trade", Journal of Computer Information Systems, 50(1): 124 - 132.

Chinn, M. D. ve Fairlie R. W. (2007) “The Determinants of the Global Digital Divide: A Cross-Country Analysis of Computer and Internet Penetration", Oxford Economic Papers, 59: 16-44.

Choi, C. (2010) "The Effect of the Internet on Service Trade", Economics Letters, 109: 102 - 104.

Clarke, G. R. ve Wallsten S. J. (2006) "Has the Internet Increased Trade? Developed and Developing Country Evidence", Economic Inquiry, 44(3): 465 - 484.

Clarke, G. R. (2008) “Has the Internet Increased Exports for Firms From Low and Middle-Income Countries?", Information Economics and Policy, 20: 16 - 37.

Freund, C. L. ve Weinhold D. (2000) "On Effect of the Internet on International Trade", Board of Governors of the Federal Reserve System International Finance Discussion Papers, Number 693: 1 - 42.

Freund, C. L. ve Weinhold D. (2002) "The Internet and International Trade in Services", American Economic Review, 92(2): 236 - 240.

Freund, C. L. ve Weinhold D. (2004) "The Effect of the Internet on International Trade", Journal of International Economics, 62: 171 - 189.

Gujarati, D. N. (2003) Basic Econometrics, 4. Edition, New York, McGraw Hill.

Karagöz, K. (2007) “Bilgi İletişim Teknolojilerindeki Gelişmenin Ihracata Etkisi: Türkiye İçin Ampirik Bir Analiz", Maliye Dergisi, 153: 214 - 223.

Lee, J. (2012) "Network Effects on International Trade", Economics Letters, 116: 199 - 201.
Lin, F. (2015) “Estimating the Effect of the Internet on International Trade", The Journal of International Trade \& Economic Development, 24(3): 409 - 428.

Meijers, H. (2014) "Does the Internet Generate Economic Growth, International Trade, or Both?", International Economics and Economic Policy, 11(1): $137-163$.

Melemen, M. (2006) "Türk İhracat Şirketlerine İnternet'in Katkıları Üzerine Bir Saha Araştırması", Öneri Dergisi, 7(25): 193 - 198.

Miraskari, S. R., Asfiji, N. S., Siadat, S. A. ve Mirasgari S. A. (2011) "The Effect of the Internet on Trade Flows", Economics and Finance Review, 1(6): 100 - 106.

Salmani, B., Saremi, M. ve Pourebrahim, F. (2013) "The Effect of the Internet on International Trade in Services: Developing Countries' Case Study", E-Commerce in Developing Countries: With Focus on e-Security (ECDC), 7th Intenational Conference, April 2013, Kish Island, Iran.

Şen, A., Çelebioğlu, F. ve Altay H. (2009) "The Effects of Knowledge and Technology Variables on Terms of Trade", Süleyman Demirel Üniversitesi Iktisadi ve Idari Bilimler Fakültesi Dergisi, 14(2): 361 - 374.

Tatoğlu, F. Y. (2013) Panel Veri Ekonometrisi, 2. Baskı, İstanbul, Beta Yayıncılık.

Timmis, J. (2012) “The Internet and International Trade in Goods", Discussion Papers in Economics, 12/03.

Vemuri, V. K. ve Siddiqi, S. (2009) "Impact of Commercialization of the Internet on International Trade: A Panel Study Using the Extended Gravity Model", The International Trade Journal, 23(4): 458 484.

Yadav, N. (2014) "The Role of Internet Use on International Trade: Evidence from Asian and SubSaharan African Enterprises", Global Economy Journal, 14(2): $189-214$.

Yurtsever, H. (2010) “Uluslararası Ödeme Şekillerinde Bankalarca Alınan Komisyon ve Vergi Üzerine Eleştirel Bir Yaklaşım", Ege Akademik Bakış, 10(3): 855 - 869.

Yushkova, E. (2014)“Impact of ICT on Trade in Different Technology Groups: Analysis and Implications", International Economics and Economic Policy, 11: 165 - 177. 
